\title{
Bovine testicular fluid enhanced growth performance of broiler chickens
}

*Ewuola, E. O. and Olujimi, A. T.

Animal Physiology and Bioclimatology Unit,

Department of Animal Science, University of Ibadan, Ibadan, Nigeria

*Corresponding author: eoewuola@gmail.com; +2348060862361

\section{Abstract}

Testosterone has been reported to have anabolic influence on various organs of animals. Thus, an experiment was carried out to investigate the influence of crude testosterone in bovine testicular fluid (BTF) on the growth performance of broiler chickens. One hundred and twenty-five broiler chicks (Abore Acre) were used. They were raised for one week and randomly allotted into five treatments consisted of five replicates (five chicks per replicate) under the intensive management system. Four different levels; $25 \mathrm{~mL}, 50 \mathrm{~mL}, 75 \mathrm{~mL}$, and $100 \mathrm{~mL}$ of bovine testicular fluid per litre of water were administered to the birds, while the control birds were offered ordinary water. Feeds (broiler starter and finisher diets) were provided ad libitum on daily basis at weeks 2-4 and 5-8, respectively and clean water was given at free choice throughout the period of the study. Average daily feed intake (ADFI), average daily water intake (ADWI), average daily weight gain (ADWG) per bird, and the feed conversion ratio (FCR) of the birds were determined. At week seven blood was sampled to assay for level of the luteinizing hormone (LH), follicle stimulating hormone (FSH), and testosterone. The results indicated that $A L W$ and the ADWG of the T5 birds $(1850.00 \mathrm{~g} / \mathrm{bird}$ and $43.79 \mathrm{~g} / \mathrm{bird}$, respectively) were significantly $(p<0.05)$ higher than birds in T1, T2, T3, and T4, while the ADFI of T1, T3 and T4 birds $(90.33 \mathrm{~g} / \mathrm{bird}, 94.09 \mathrm{~g} / \mathrm{bird}, 90.39 \mathrm{~g} / \mathrm{bird}$ respectively) were significantly $(P<0.05)$ higher than $T 2(84.60 \mathrm{~g} / \mathrm{bird})$ and $T 5$ (84.60g/bird). ADWI of the T5 and T4 birds $(101.01 \mathrm{~mL} / \mathrm{bird}$, and $98.68 \mathrm{~mL} / \mathrm{bird}$, respectively) were significantly $(P<0.05)$ higher than TI $(82.13 \mathrm{~mL} / \mathrm{bird}), T 2(86.50 \mathrm{~mL} / \mathrm{bird})$ and $T 3$ (93.01mL/bird) birds. Birds administered $100 \mathrm{~mL}$ of BTF/litre (T5) had the best percentage carcass yield and feed conversion ratio of $76.60 \%$ and 2.11 respectively, among the treatments T1, T2, T3, and T4 birds. The result of the enzyme-linked immunosorbent assay of the serum concentration of the sex hormones showed that the expression of the serum testosterone increased as the inclusion levels of the Bovine testicular fluid increased with birds on T5 having significantly $(P<0.05)$ higher values $(3.64 \mathrm{nmol} / \mathrm{L})$ than those on the control $(2.60 \mathrm{nmol} / \mathrm{L})$. However, testosterone levels in T2 $(3.18 \mathrm{nmol} / \mathrm{L}), T 3(3.24 \mathrm{nmol} / \mathrm{L})$ and T4 (3.40 nmol/L) was not significantly different from T5. This study suggests that $100 \mathrm{ml}$ of bovine testicular fluid per liter of the drinking water can be used as a growth promoter for broiler chickens.

Keywords: Broiler chickens, Natural growth promoter, Bovine testicular fluid, Crude testosterone

\section{Introduction}

Poultry production is the easiest way by which the domestic consumption of animal protein among the average Nigeria citizens can be increased. This is because the establishment of poultry enterprise does not require huge capital like that of other livestock enterprise such as sheep, goat and cattle. Besides poultry production is an effective pathway by which poverty rate can be reduced in Nigeria through the provision of employment as a means of livelihood among the ever-increasing unemployed people.

The major constraint of poultry production in Nigeria can be attributed to the high cost of feed ingredient as it gulps $6080 \%$ of the cost of production and the occasional 


\section{Bovine testicular fluid enhanced growth performance of broiler chickens}

adulteration of the conventional protein supplements such as soya bean meal, fishmeal and groundnut cake by the feed ingredient suppliers (Larry 1993, Adejinmi et al., 2000). Exposure of broiler chickens to chronic heat stress has been confirmed as another factor that causes the deterioration of most of the production parameters (Bonnet et al., 1997, Cooper and Washbum, 1998), as a result of high environmental temperature, which imposes environmental stress response on the commercial broiler chickens in the tropical region particularly in Nigeria by reducing feed intake, cause stunted growth, altered haematological parameters and eventually death. Before now antibiotic and antifungals have been the backbone of therapeutic drugs used to promote the growth and welfare of broiler chickens, in the phase of this environmental stress but there appear to be rapid global shift recently towards the use of antibiotic drug as a growth promoter in broiler chicken production as it has been found to compromised the efficacy of such antibiotic in human, the consequence of which has led to the ban in the use of antibiotic drug additive in animal production by the European countries authorities and which has now being emulated by other nations of the world (Schwarz et al., 2001 and Shane, 2001).

In view of this there is need to search for other growth promoting agent that will be effective for broiler production either through feed or water. The use of water additive such as testicular fluid that is cheap and easily available in abattoir as waste product is promising alternative.

According to Isidari et al. (2005) and Yanezawa et al. (2012), testosterone has been reported to have anabolic effects and the potential to combine with other steroid hormones to influence various organs including muscular system, digestive system and heart (Muthsamy et al., 2011), by improving the rate of weight gain and feed efficiency in animals (Annamaria, 2012). The consequences of which has resulted to the increase in the rate at which muscle grows by about $10-30 \%$ thereby reducing the time the animal needs to spend on feed before reaching slaughter weight (Hunter, 2010). Therefore, this present study was designed to harness this potential and assess the effect of inclusion of different levels of crude testosterone hormone in bovine testicular fluid on the growth indices of broiler chickens.

\section{Materials and methods Experimental site/location}

The experiment was carried out at the Poultry Unit of the Teaching and Research Farm, University of Ibadan, Ibadan, Nigeria.

Preparation and determination of the crude testosterone

The testes of a healthy mature bull were procured weekly at the Bodija International abattoir market, Ibadan, Oyo State. The weight of the testes was measured, macerated and homogenised without the tunica albuginea in the Animal Physiology and Bioclimatology Unit Laboratory of the Department of Animal Science, University of Ibadan, in $30 \mathrm{~mL}$ of normal saline solution (physiologically saline) per gram of the testes. The homogenate was sieved using gauze, and then centrifuged using a centrifuge model of BOSH 90-2 at 1500 rpm for five minutes and the supernatant was decanted into a sterile sample bottle and stored at $4^{\circ} \mathrm{C}$ in the refrigerator as bovine testicular fluid (BTF).

Experimental diets and management of birds

A total number of 125 unsexed day-old chicks were procured from a reputable hatchery in Ibadan. The chicks were raised for one week after which they were randomly allotted into 25 equal size pens 


\section{Ewuola and Olujimi}

which have been thoroughly washed and disinfected prior to the arrival of the chicks from the hatchery. This is divided into 5 treatment groups, each with five replicates of 5 chicks per replicate. The birds were offered feed ad libitum in the first four weeks (starter diet) and the last three weeks (finisher diet) of the experiment (Table 1) with free choice access to water intake. Five treatments were administered to the birds orally which include $0 \mathrm{ml}$, (control), $25 \mathrm{ml}, 50 \mathrm{ml}, 75 \mathrm{ml}$, and $100 \mathrm{ml} \mathrm{BTF}$ per liter of drinking water for 49 days.

\section{Data collection}

The average daily feed and water intake of the birds were estimated every day. The average daily feed and water intake of the birds were calculated everyday as the amount of feed or water supplied minus left over. The average weight gain of the birds was measured on weekly basis by deducting the initial body weight from the final weight, which was later used to determine the feed conversion ratio of the birds by dividing the average feed intake of the birds by the average weight gain.

\section{Sex hormonal assay}

At the end of the experiment blood was sampled from the birds to determine circulatory sex hormones (luteinizing hormone, follicle stimulating hormone and testosterone) as described in Ewuola and Olaleye (2015) using Enzyme linked immunosorbent assay kits.

\section{Organ assessment}

Thereafter, two birds were sacrificed per replicate, defeathered, weighed to determine the carcass yield. The relative weight of the internal organs and intestine were calculated after weighing relative to liveweight.

\section{Data analysis}

All data obtained from the study were subjected to one-way analysis of variance procedures of the Statistical Analysis System (SAS, 2003). Treatment means were separated using Duncan's Multiple range test of the same software.

Table: 1 The gross composition $(\mathrm{g} / 100 \mathrm{~g})$ of the experimental diet

\begin{tabular}{|c|c|c|}
\hline \multirow[b]{2}{*}{ Ingredients } & \multicolumn{2}{|c|}{ Broiler diets } \\
\hline & Starter phase & Finisher phase \\
\hline Maize & 51.50 & 61.80 \\
\hline Soyabean meal & 41.8 & 35.00 \\
\hline Soya oil & 4.50 & 1.00 \\
\hline $\mathrm{DCP}$ & 1.20 & 1.20 \\
\hline Limestone & 0.40 & 0.40 \\
\hline Salt & 0.25 & 0.25 \\
\hline Lysine & 0.10 & 0.10 \\
\hline Vit/Tm premix* & 0.25 & 0.25 \\
\hline Total & 100 & 100 \\
\hline \multicolumn{3}{|c|}{ Calculated Nutrients } \\
\hline $\mathrm{ME} \mathrm{Kcal/Kg}$ & 3035.39 & 2934.80 \\
\hline $\mathrm{CP}(\mathrm{g} / \mathrm{kg})$ & 227.695 & 206.53 \\
\hline Calcium (g/Kg) & 5.44 & 5.26 \\
\hline Total P (g/Kg) & 6.11 & 5.92 \\
\hline NPP $(g / K g)$ & 3.49 & 3.35 \\
\hline Fat $(\mathrm{g} / \mathrm{Kg})$ & 35.23 & 36.97 \\
\hline Crude fibre $(\mathrm{g} / \mathrm{Kg})$ & 40.59 & 38.10 \\
\hline \multicolumn{3}{|l|}{ Amino acids } \\
\hline Methionine $(\mathrm{g} / \mathrm{Kg})$ & 3.52 & 3.28 \\
\hline Lysine $(\mathrm{g} / \mathrm{Kg})$ & 13.58 & 12.02 \\
\hline
\end{tabular}




\section{Bovine testicular fluid enhanced growth performance of broiler chickens}

\section{Results and discussion}

\section{Growth performance of the experimental} birds

The growth response of broiler chickens administered bovine testicular fluid is presented in Table 2. There was nonsignificant difference across the treatments in the daily feed intake of the birds. The T3 birds had the highest daily feed intake of $94.09 \mathrm{~g} /$ bird followed by the T4 $(90.34 \mathrm{~g})$, T1 (90.33g), T2 (84.60g) and T5 had the least feed intake of $84.60 \mathrm{~g}$. There were significant $(\mathrm{P}<0.05)$ differences in water intake across the groups the water intake increased with the inclusion levels of the crude testosterone. Birds on T5 had the highest daily average water intake of $101.01 \mathrm{~mL}$ followed by T4 $(98.68 \mathrm{~mL}), \mathrm{T} 3$ $(93.01 \mathrm{~mL}), \mathrm{T} 2(86.50 \mathrm{~mL})$ and the control bird (T1) had the least water intake of $82.13 \mathrm{~mL}$. The live weight varied significantly $(\mathrm{P}<0.05)$ across the treatments. Weight gain significantly $(\mathrm{P}<0.05)$ increased as the inclusion levels of the crude testosterone increased in the drinking water with the T5 birds having the highest average daily weight gain of $43.79 \mathrm{~g}$ followed by T4 (34.53g), T3 (34.37g), T2 (23.76g), while the T1 had the least average daily weight gain of $22.06 \mathrm{~g}$. The results of the growth performance of broiler chickens had shown that the live weight and the weight gain of the broiler chickens increased as the levels of the bovine testicular fluid administered increased, this implies that the metabolic efficiency and dietary utilization by the birds were improved by the treatments. This also suggested that the inclusion of the bovine testicular fluid in the water reduced the adverse effects of the hot climate on the performance of the birds probably by increasing the availability of nutrients and energy to the animals for growth which facilitate the increased in weight gain of the birds as the inclusion levels of the bovine testicular fluid increases. This correspond with the reports of Egbunike et al. (2007) and Adejinmi et al. (2015) that bovine testicular fluid which consist of crude testosterone can be used to improve the growth performance of broiler chicken's production in the tropical region where high environmental temperature has been the major treat to the growth of broiler chickens (Adejumo et al., 1984).

Table 2: The Growth performance of the broiler chickens offered different levels of Bovine testicular fluid

\begin{tabular}{|c|c|c|c|c|c|c|}
\hline \multirow[b]{3}{*}{ Parameters } & \multicolumn{5}{|c|}{ Bovine testicular fluids } & \multirow{3}{*}{ P value } \\
\hline & T1 (Control) & $\mathrm{T} 2(25 \mathrm{ml} / \mathrm{L})$ & T3 (50ml/L) & $\mathrm{T} 4(75 \mathrm{ml} / \mathrm{L})$ & T5 $(100 \mathrm{ml} / \mathrm{L})$ & \\
\hline & & & & & & \\
\hline IBW $(g)$ & $113.84 \pm 5.87^{\mathrm{ab}}$ & $124.40 \pm 0.14^{\mathrm{a}}$ & $108.76 \pm 3.58^{b}$ & $108.48 \pm 2.71^{b}$ & $117.12 \pm 3.76^{b}$ & 0.04 \\
\hline ALW (g) & $1157.14 \pm 48.09^{c}$ & $1325.00 \pm 45.32^{b c}$ & $1437.50 \pm 75.45^{\mathrm{ab}}$ & $1487.50 \pm 38.81^{\mathrm{ab}}$ & $1850.00 \pm 88.64^{\mathrm{a}}$ & 0.04 \\
\hline $\operatorname{ADWG}(\mathrm{g})$ & $22.06 \pm 1.53^{\mathrm{c}}$ & $23.76 \pm 0.72^{c}$ & $34.37 \pm 1.57^{\mathrm{b}}$ & $34.53 \pm 1.24^{\mathrm{b}}$ & $43.79 \pm 2.19^{\mathrm{a}}$ & 0.01 \\
\hline $\begin{array}{l}\text { Carcass } \\
\text { yield }(\%)\end{array}$ & $57.90 \pm 0.39^{c}$ & $60.51 \pm 1.14^{\mathrm{c}}$ & $71.57 \pm 0.70^{b}$ & $74.79 \pm 0.74^{\mathrm{ab}}$ & $76.60 \pm 2.18^{\mathrm{a}}$ & 0.01 \\
\hline FCR & $4.20 \pm 0.12^{\mathrm{a}}$ & $3.58 \pm 0.12^{\mathrm{b}}$ & $2.76 \pm 0.13^{c}$ & $2.63 \pm 0.09^{\mathrm{cd}}$ & $1.93 \pm 0.11^{\mathrm{d}}$ & 0.01 \\
\hline ADFI (g) & $90.33 \pm 3.27^{\mathrm{a}}$ & $84.60 \pm 1.02^{b}$ & $94.09 \pm 1.02^{\mathrm{a}}$ & $90.39 \pm 0.31^{\mathrm{a}}$ & $84.60 \pm 2.20^{b}$ & 0.81 \\
\hline ADWI (mL) & $82.13 \pm 1.48^{\mathrm{d}}$ & $86.50 \pm 1.46^{c}$ & $93.01 \pm 1.55^{\mathrm{b}}$ & $98.68 \pm 1.24^{\mathrm{a}}$ & $101.01 \pm 0.77^{\mathrm{a}}$ & 001 \\
\hline
\end{tabular}

As presented in Table 2, the feed conversion ratio varied significantly $(\mathrm{P}<0.05)$ across the treatments. Control birds had the highest FCR of (4.20) followed by the birds on T2 (3.58), T3 (2.76), T4, (2.63) and birds on T5 had the least FCR of 1.93. The carcass yield varied $(\mathrm{P}<0.05)$ significantly across the treatments. It was observed that 


\section{Ewuola and Olujimi}

the T5 had $76.60 \%$ carcass yield followed by T4 $(74.79 \%)$, T3 $(71.57 \%)$, T2 $(60.51 \%)$. The control group (T1) had the least carcass yield of $57.90 \%$. This suggest that the increase in the levels of the bovine testicular fluid facilitated the increased in the carcass yield and also improved the feed conversion ratio of the birds by increasing the rate at which the muscles grown and reduced the quantity of feed intake needed by the broiler chickens to reach the slaughter weight. This also corresponded with the finding of Annemaria et al. (2012) that testosterone in combination with other active hormone substance can be used to improve the weight gain and the feed conversion ratio of broiler chickens. This suggest that the bovine testicular fluid consist of other androgen hormones such as luteinizing hormone, follicle stimulating hormone and testosterone which probably worked synergically with testosterone to enhance increase in living substance/protoplasm that may include cell multiplication (hyperplasia), cell enlargement (hypertrophy) (Peric et al., 2009; Annemaria et al., 2012). This resulted to the increase in weight gained and the carcass yield for all the birds offered different levels of the bovine testicular fluid.

It was observed that the birds that received the bovine testicular fluid had better feed conversion ratio than the control birds, this might be due to the crude testosterone which facilitated the efficiency of the FCR and the quick released of the nutrients (protein, energy and fat) needed for the muscle growth from the feed with the birds administered 100MLBTF/L having the best feed conversion ratio (although the entire treatment birds performed better than the control). This agrees with the report of Pym and Solvyns (1997) and Peric et al. (2009) who reported that growth promoter has beneficial effects of transfer energy from feed to tissue thereby improve the feed conversion ratio.

The present research observed that the feed intake and the FCR of the birds were proportional to the weight gain which suggested that the crude testosterone present in the testicular fluid had increased the rate at which the muscle grow thereby reduced the time the animal needed to spend on feed before reaching slaughter weight (Hunter, 2010). The result showed that there were significance differences in the water intake of the treatment birds. This could be attributed to the bovine testicular fluid which accelerated the rate at which the birds obtained the energy from metabolic functions (digestion, the absorption and utilization of the nutrients) and growth for their feed in form of carbohydrates, proteins and fat which in turn increased the internal heat generated by the birds and which necessitated the birds to seek cooling effect from drinking water. Furthermore, the increased levels of the water intake by the birds could be as a result of the high environmental temperature which necessitated the birds to cool its internal environmental temperature. This agree with the finding of Daghir (1995) and Daghir et al. (2013) that drinking water has an important role in hot weather particularly to maintain homeostasis.

\section{Sex hormones in broiler chickens administered bovine testicular fluid}

The result of the enzyme-linked immunosorbent assay of the serum concentration of the sex hormones is presented in Table 4 and showed that the expression of the serum testosterone increased as the inclusion levels of the crude testosterone with birds on T5 having significantly $(\mathrm{P}<0.05)$ higher values $(3.64$ $\mathrm{nmol} / \mathrm{L})$ than those on the control $(2.60$ $\mathrm{nmol} / \mathrm{L})$. However, testosterone levels in T2 (3.18 nmol/L), T3 (3.24 nmol/L) and T4 (3.40 nmol/L) were not significantly 


\section{Bovine testicular fluid enhanced growth performance of broiler chickens}

Table 3: The relative weight of the internal organs of broiler chickens administered different levels of Bovine testicular fluid

\begin{tabular}{|c|c|c|c|c|c|c|}
\hline \multirow[b]{2}{*}{ Parameters (\%) } & \multicolumn{5}{|c|}{ Bovine testicular fluids } & \multirow[b]{2}{*}{ P value } \\
\hline & T1 (Control) & $\mathrm{T} 2(25 \mathrm{ml} / \mathrm{L})$ & $\mathrm{T} 3(50 \mathrm{ml} / \mathrm{L})$ & $\mathrm{T} 4(75 \mathrm{ml} / \mathrm{L})$ & T5 $(100 \mathrm{ml} / \mathrm{L})$ & \\
\hline Kidney & $1.33 \pm 0.69$ & $1.78 \pm 1.05$ & $0.63 \pm 0.02$ & $0.72 \pm 0.02$ & $0.72 \pm 0.05$ & 0.52 \\
\hline Liver & $2.83 \pm 0.17$ & $2.15 \pm 0.35$ & $3.10 \pm 1.30$ & $2.42 \pm 0.15$ & $2.95 \pm 0.13$ & 0.29 \\
\hline Pancreas & $0.41 \pm 0.04^{\mathrm{a}}$ & $0.35 \pm 0.02^{\mathrm{a}}$ & $0.31 \pm 0.02^{\mathrm{b}}$ & $0.33 \pm 0.02^{\mathrm{b}}$ & $0.32 \pm 0.23^{b}$ & 0.06 \\
\hline Intestine & $17.98 \pm 0.74^{\mathrm{a}}$ & $15.59 \pm 0.62^{b}$ & $13.69 \pm 0.68^{b c}$ & $14.15 \pm 12.56^{\mathrm{bc}}$ & $12.13 \pm 1.30^{\mathrm{c}}$ & 0.01 \\
\hline Gizzard & $4.35 \pm 0.130^{\mathrm{a}}$ & $3.66 \pm 0.19^{b c}$ & $3.40 \pm 0.10^{c}$ & $4.14 \pm 0.31^{\mathrm{ab}}$ & $3.47 \pm 0.25^{\mathrm{c}}$ & 0.01 \\
\hline Bile & $1.14 \pm 0.69^{\mathrm{a}}$ & $0.06 \pm 0.01^{\mathrm{b}}$ & $0.04 \pm 0.00^{\mathrm{b}}$ & $0.09 \pm 0.05$ & $0.03 \pm 0.00^{\mathrm{b}}$ & 0.05 \\
\hline Spleen & $0.12 \pm 0.02^{\mathrm{b}}$ & $0.29 \pm 0.15^{b}$ & $1.59 \pm 0.93^{\mathrm{a}}$ & $0.11 \pm 0.02^{b}$ & $0.12 \pm 0.02^{b}$ & 0.09 \\
\hline Heart & $0.41 \pm 0.07^{\mathrm{ab}}$ & $0.48 \pm 0.02^{\mathrm{a}}$ & $0.47 \pm 0.03^{\mathrm{ab}}$ & $0.49 \pm 0.01^{\mathrm{a}}$ & $0.36 \pm 0.05^{b}$ & 0.10 \\
\hline Empty gizzard & $2.25 \pm 0.17^{\mathrm{ab}}$ & $2.42 \pm 0.24^{\mathrm{a}}$ & $1.71 \pm 0.10^{\mathrm{bc}}$ & $2.11 \pm 0.16^{\mathrm{ab}}$ & $1.50 \pm 0.27^{\mathrm{c}}$ & 0.01 \\
\hline Adrenal & $0.34 \pm 0.32^{\mathrm{a}}$ & $0.01 \pm 0.00^{\mathrm{b}}$ & $0.02 \pm 0.00^{\mathrm{b}}$ & $0.04 \pm 0.00^{\mathrm{b}}$ & $0.64 \pm 0.00^{\mathrm{a}}$ & 0.12 \\
\hline Bursa & $0.07 \pm 0.02^{b}$ & $0.10 \pm 0.02^{\mathrm{b}}$ & $0.45 \pm 0.26^{\mathrm{a}}$ & $0.06 \pm 0.00^{\mathrm{b}}$ & $0.05 \pm 0.01^{\mathrm{b}}$ & 0.11 \\
\hline Lung & $0.44 \pm 0.10$ & $0.56 \pm 0.03$ & $0.60 \pm 0.03$ & $0.51 \pm 0.01$ & $0.46 \pm 0.10$ & 0.35 \\
\hline Testes & $0.24 \pm 0.14$ & $0.03 \pm 0.01$ & $0.18 \pm 0.10$ & $0.03 \pm 0.01$ & $0.32 \pm 0.20$ & 0.24 \\
\hline Abdominal fat & $0.46 \pm 0.16^{\mathrm{b}}$ & $0.52 \pm 0.15^{\mathrm{b}}$ & $0.30 \pm 0.11^{b}$ & $1.14 \pm 0.24^{\mathrm{a}}$ & $0.36 \pm 0.12^{b}$ & 0.01 \\
\hline Head & $1.65 \pm 0.11^{\mathrm{a}}$ & $1.37 \pm 0.06^{\mathrm{b}}$ & $1.43 \pm 0.10^{\mathrm{ab}}$ & $1.64 \pm 0.06^{\mathrm{a}}$ & $1.35 \pm 0.10^{\mathrm{b}}$ & 0.04 \\
\hline
\end{tabular}

Table 4: The serum hormonal assay of the broiler chickens offered different levels of crude testosterone in Bovine testicular fluid

\begin{tabular}{|c|c|c|c|c|c|c|}
\hline \multirow[b]{2}{*}{ Parameters } & \multicolumn{5}{|c|}{ Bovine testicular fluids } & \multirow[b]{2}{*}{ P value } \\
\hline & $\begin{array}{c}\text { T1 } \\
\text { (Control) }\end{array}$ & $\begin{array}{c}\mathrm{T} 2 \\
(25 \mathrm{ml} / \mathrm{L})\end{array}$ & $\begin{array}{c}\mathrm{T3} \\
(50 \mathrm{ml} / \mathrm{L}) \\
\end{array}$ & $\begin{array}{c}\mathrm{T} 4 \\
(75 \mathrm{ml} / \mathrm{L})\end{array}$ & $\begin{array}{c}\text { T5 } \\
(100 \mathrm{ml} / \mathrm{L})\end{array}$ & \\
\hline LH (IU/L) & $20.20 \pm 0.86^{\mathrm{a}}$ & $14.60 \pm 0.51^{b}$ & $16.00 \pm 1.00^{\mathrm{b}}$ & $16.20 \pm 1.00^{\mathrm{b}}$ & $16.40 \pm 0.51^{\mathrm{b}}$ & 0.0009 \\
\hline FSH (IU/L) & $16.80 \pm 0.66^{\mathrm{a}}$ & $12.00 \pm 0.71^{b}$ & $12.00 \pm 1.10^{\mathrm{b}}$ & $13.60 \pm 0.68^{\mathrm{b}}$ & $12.80 \pm 0.58^{\mathrm{b}}$ & 0.0013 \\
\hline $\begin{array}{l}\text { Testosterone } \\
(\mathrm{nmol} / \mathrm{L})\end{array}$ & $2.50 \pm 0.45^{b}$ & $3.18 \pm 0.35^{\mathrm{ab}}$ & $3.24 \pm 0.16^{\mathrm{ab}}$ & $3.40 \pm 0.38^{\mathrm{ab}}$ & $3.64 \pm 0.16^{\mathrm{a}}$ & 0.1840 \\
\hline
\end{tabular}

different from T5. The FSH and LH were significantly $(\mathrm{P}<0.05)$ higher in the birds administered $\mathrm{T} 1$ than those on T2, T3, T4 and T5. This shows that the testicular fluid consists of LH, FSH and the testosterone hormones which worked synergically to increase the rate at which the muscle grew with less feed intake compared to the control birds. According to Egbunike (2007) and Annemaria (2012) they reported that testosterone can work in combination with other hormones to improve the feed conversion ratio and the growth rate of birds. This suggested that testosterone seems to be the active hormones which facilitated the increase in the live weight of the birds as a result of the increased in the muscle mass of the treated birds which increases as the inclusion levels of the testicular fluid extract increases in the drinking water.

\section{Relative organ weight of the broiler chickens administered Bovine testicular fluid}

It was found that there was no significance difference in the values obtained for the kidney, liver, pancreas, spleen, heart, adrenal, lungs and testis but significance difference was observed in the values obtained for the intestinal weight, intestinal percentage, intestinal length, gizzard, bile, empty gizzard, abdominal fat and the testes 


\section{Ewuola and Olujimi}

across the treatments. The relative weights of some internal organs such as liver, lung, kidney that were not affected by the treatments agrees with the findings of Adejinmi (2015), and Dizaji, et al. (2013) who reported that growth promoters did not affect internal organs and also the report of Zakia et al. (2008), which suggested that the metabolic heat generated as a result of increase in the muscle growth in combination with multiple environmental stress may have probably affected the weight of other internal organs of the treatment birds.

\section{Conclusion}

The study showed that bovine testicular fluid increased the growth rate and the efficiency of feed conversion with improved carcass yield which is directly proportional to its level in the drinking water. Inclusion level of the bovine testicular fluid at $100 \mathrm{~mL} /$ Liter of drinking water gave the best performance. The presence of the fluid stimulated and increase in the titter level of FSH and testosterone but reduced Luteinizing hormone.

\section{References}

Adejinmi, O. O., Adejinmi, J. O. and Adeleye, I. O. A. 2000 . Replacement of Fish meal with Soldier fly larvae meal in broiler diets. Nig. Poult. Sci. J. 1:5260

Adejinmi, O. O., Tolulope, J. W., Odetola, O. M., Monsuru, O. A. 2015. Growth, Performance and Carcass Yield of Broilers Fed Standard and Low Protein Feeds with Inclusion of Dietary Crude Testosterone. Correspondence: Odetola Olubayo Michael, Federal College of Animal Health and Production Technology, Moor Plantation, Ibadan, Nigeria.
Journalof Agricultural

Science; Vol. 7, No. 9; 2015

Adejumo, D. O and Egbunike, G. N 1984. Effect of Thermal Stress and water $\mathrm{D}$ e $\mathrm{p} \mathrm{r}$ i v a $\mathrm{t}$ i o $\mathrm{n} \quad \mathrm{o} \mathrm{n}$ Acetylcholinesterase Activity in Pig Brain and Hypophyses int J. biometer 312108.111

Annamaria, P. 2012. Steroid hormones in food producing animals: A bird'seye view of $\quad \mathrm{v}$ e t e r i n a r y medicine. Inc. C. Perez-Marin (Ed.), In Tech. Retrieved from h t t p:// w w w. in techopen .com/books/a-bird-s-eye-view-ofveterinary-medicine/title-steroidhormones-in-foodproducinganimals-regulatory-situation-ineurope

Bonnet, S. P. A Geraert, M. Lessire, B. Carre and S. Cullaumn. 1997. Effect of high ambient temperature on feed digestibility in broilers. Poult. Sc, 76:857-863

Cooper, M. A., Washburm, K. W. 1998. The relationships of body temperature and weight gain, feed consumption, and feed utilization in broilers under heat stress poultry Sci. 1998

Daghir, N. J. 1995. Poultry Production in hot climates. Cambridge: CAB International.

Daghir, N. J, Beirut and Lebanon. 2013. Nutritional Stractegies to Reduce Heat Stress in Broiler and Broiler Breeders. Lohmann information, 44:6-158

Dizaji, B. R., Zakeri, A., Golbazfarsad, A., F a r a marzy, S., and Ranjbari, O. 2013. Influences of different growth promoters on intestinal morphology of broiler chickens. European Journal of Experimental Biology, 3(2): 3237. 


\section{Bovine testicular fluid enhanced growth performance of broiler chickens}

Egbunike, G. N., Williams, T. J., and Agiang, E.A. 2007. Utilization of crude testis extract to enhance broiler Production in the Humid Tropics. Global journal of agriculturalsciences vol. 7 no. 12008: $27-30$

Ewuola, E. O and Olaleye T. O. 2015. Serum and testicular glucose, total protein and sex hormone profile of mottled brown male Japanese quails. Trop. Anim. Prod. Invest.18(2):75-83.

Hunter, R. A. 2010. Hormonal growth promotant use in the Australian beef industry. Animal Production Science, 50: 637-659

Isidari, A. M, Giannnetta, E, Gianfrilli, D, Greco, E. A, Gianfrilli, D, Bonifacio, V, Isidiori A, Lenzi, A, and Fabbri, A. 2005. Effects of testosterone on body composition, bone metabolism and serum lipid profile in middle age men: a metaanalysis. Clinical Endocrinology, 63: 280293.

Larry, E. N. 1993. Broiler feeding and management J. Poultry Science International, 32(1), 70- 72.

Muthusamy, T, Murugesan, P, S r i n i v a a n, C a n d Balasubramanian, K. 2011. Sex steroid influence glucose oxidation through modulation of insulin receptor expression and IRSI serine phosphorylation in target tissues of adult male rat. Mol Cell Biochem. 352(12): 3545.

Peric, L., Zikic, D. and Lukic, M. 2009. Application of alternative growth promoters in broiler production. Biotech. Anim. Husb., 25:387-397.

Pym R, and Solvyns A 1979: Selection for food conversion in broilers: body composition of birds selected for increased body-weight gain, food consumption and food conversion ratio. $\mathrm{Br}$ Poult Sci 20(1): 87-97. doi: 10.1080/00071667908416552Cro ssRefGoogle Scholar

Schwarz, S., C. Kehrenberg and T. R. Walsh, 2001. Use of antimicrobial agents in veterinary medicine and food animal production. Int. $J$. Antimicrob. Agents. 17, 431-437.

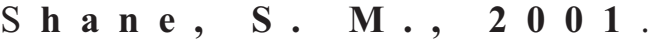
Mannanoligosaccharides in poultry nutrition: mechanisms and benefits. pp.65-77. in $\mathrm{T}$. $\mathrm{P}$. Lyons, ed. Proc. Of Alltech's 17 Annu.Symp., Biotechn. In the Feed Industry. Alltech Technical Publications, Nottingham University Press, Nicholasville, KY. Spsswin, 1994:

Yonezawa, R, Wads, T, Matsumato, N, Morita, M, Sawakawa, K, Ishii, Y, Sasahara M, Tsuneki H, Saito S, and Sasaoka T. 2012. Central versus peripheral impact of estradiol on the impaired glucose metabolism in ovariectomized mice on a highfat diet. Am. $J$. Physiol. Endocrinol. Metab. 15:303 (4): E44556.

Zakia, A., Ahmed, M and Zahra,'A. H., El - Ghamdi. 2008. Multiple environmental stresses and broiler internal organs somatic indices under controlled environment. Int. Journal of Poultry Science. 7:1089-1094.

Received: $7^{\text {th }}$ November, 2018 Accepted: $9^{\text {th }}$ February, 2019 